\title{
União homoafetiva no âmbito jurídico do direito brasileiro: a travessia que não se completou
}

\author{
Liliane Cristina da Silva Souza ${ }^{1}$ \\ Lourival José de Oliveira ${ }^{2}$
}

\begin{abstract}
Resumo
0 presente artigo tem a finalidade de compulsar o estudo sobre a União Homoafetiva no âmbito familiar, enveredando sobre as relações homossexuais, que a cada dia vem subindo mais um degrau contra o preconceito que assola na sociedade, notando-se também a bipartição sócio-jurídica na forma de encarar os que se encontram fora de um 'padrão' conceituado culturalmente como 'socialmente aceito', na realidade, favorece a ocorrência de um 'modus operandi' discriminatório, cujos primórdios encontram-se desde os índios até os homossexuais. E neste diapasão, é que irá se indagar que motivo teria o Direito, de não amparar as relações afetivas de pessoas de mesmo sexo, ou seja, da lei não normatizar a união homossexual como um instituto 'sui generis' do direito de família, embora haja alguns Estados equiparando a união homossexual não como um casamento, mas como união estável ou de fato. Infere-se então que tal interrogação não obtenha uma resposta, mas que venha a conduzir pensamentos em torno deste tema, para que possivelmente surjam soluções, que poderão contribuir para uma vida mais digna dos homossexuais.
\end{abstract}

Palavras-Chave: Homossexualidade; Afeto, Ordenamento jurídico.

\section{Introdução}

Ao contrário do que muitos possam vir a pensar, a homossexualidade ocorre desde os primórdios da evolução humana, e, por conseguinte, acalenta o coração de muitos seres humanos. Embora, desde o nascer, o ser humano chora pelo que é novo, e no decorrer de sua vida ignora ou repudia quaisquer fatos inerentes ao seu desconhecimento. E apesar de ser uma sociedade denominada "moderna”, ainda, com sua 'modernidade' prefere banalizar a criminalidade a ignorar um preconceito.

O tema da sexualidade alheia vem tomando corpo gradativamente, quando se debate o caso Cássia Eller e Chicão, a prostituição, questões de pedofilia, dentre outras tantas situações expostas no cotidiano dos brasileiros, chocando a população que ao mesmo

\footnotetext{
${ }^{1}$ Autora; Advogada; Pós-Graduada em Direito Empresarial, CPF: 739.726.062-49.

2 Co-autor; professor do Curso de Direito da Universidade Estadual de Londrina; professor do Curso de Mestrado da Universidade Estadual de Londrina; professor do Curso de Direito da Universidade Norte do Paraná; professor do Curso de Mestrado em Direito da Universidade de Marília; professor do Curso de Direito da FACCAR.
} 
tempo, parece estar com os olhos vendados, mas os objetivos de colocar em autos, estes exemplos, só ocorrem para que se enxerguem outros fatos que também estão precisando de um socorro maior do direito brasileiro.

No que tange a homossexualidade, há uma posição hipócrita de uma parte da sociedade que a dicotomisa entre os que enfrentam a realidade do país como um ambiente único de liberdade, respeitando-o sob o comando legal e aqueles que, ao arrepio da lei e na contramão de um dos princípios basilares dessa mesma sociedade se mantêm num pedestal ético-moralista equivocado.

Deve-se ressaltar que 0 artigo abordado se delimitará no homossexual, com o teor próprio da palavra, ou seja, segundo o que a morfologia explica: 'homo', igual, ou seja, pessoas que gostam de seres de seu mesmo sexo. Assim deixando de citar outros homossexuais que analisando também necessitam do amparo jurídico-social.

Tanto que o objetivo deste artigo estará buscando o motivo do não reconhecimento da união homoafetiva no ordenamento jurídico. E para que se alcançasse o porquê deste repúdio jurídico é que abordará: a evolução da homossexualidade; os seus aspectos: religioso, psicológico e médico; e por fim, colocar em discussão o motivo que muitos legisladores, juristas, advogados, políticos, enfim, a sociedade, não normatizam a situação da união dos homossexuais.

No decorrer deste artigo ficará claro, o motivo desta omissão, tornando-se em vão tal timidez, pois é mais que lúcido que tal acontecimento, praticamente já se tornou cotidiano na vida social de todo o mundo, mas enfim, por tudo isto que de maneira sucinta este artigo está sendo feito, para por um fim a indagação que está em voga não só entre os brasileiros como também em toda a população terrestre.

\section{A Evolução histórica da homossexualidade}

Antes de argumentações sobre o desenrolar da vida destes indivíduos, tão igual quanto aos demais seres humanos, faz-se necessário entender dois aspectos sobre esta relação tão antiga quanto à relação entre homens e mulheres.

0 primeiro aspecto é em virtude do sentimento que une os seres humanos de uma maneira única e particular, ou seja, o amor, que aproxima tanto homens como mulheres independentemente de sua relação sanguínea e que por conseguinte, existem entre os 
relacionamentos homossexuais como heterossexuais, apesar de que no contexto deste amor que a muitos traz repulsa, assim, ao contrário do que se pensa, na relação homossexual também há a cobrança do afeto, compatibilidade, e outros adjetivos que vêm a definir 0 amor. 0 segundo aspecto consiste no entendimento morfológico da palavra homossexualidade, que trará grande parcela de entendimento e compreensão sobre o tema abordado. No caso da palavra homossexual, esta vem a ser formado pela união de dois vocábulos, o primeiro, 'homo' é advindo do grego 'hómus', que vem a significar semelhante, o segundo vocábulo é de origem latina, 'sexu', relativo ou pertencente ao sexo. Da união destes vocábulos dá-se a acepção de uma prática sexual entre pessoas do mesmo sexo.

Como já narrado anteriormente, a prática homossexual vem evoluindo conforme 0 crescimento de toda a humanidade, embora tão pouco ilustrada, antigamente a sociedade era conivente com esta relação, porém, como afirma alguns estudiosos, havia limites impostos, como a proibição da união desta relação homossexual, muito embora na Grécia antiga, por exemplo, a homossexualidade fora denominada como pederastia, que vem a ser a relação sexual dentre dois homens, onde geralmente se dava entre um homem com mais ou menos trinta anos e um adolescente com catorze a dezesseis anos, ou seja, o fato de um homem possuir relações com outro, não era motivo deste mesmo homem não ter uma esposa, e muito menos deste manter-se casado. Condenável era a busca simplesmente pelo sexo, pois, por mais inaceitável que seja para os olhos de muitos, os gregos desta época tinham como prioridade o amor, e por ele, 'tudo' era possível. Diante desta assertiva, a desembargadora M aria Berenice elucida:

\footnotetext{
Encaravam a homossexualidade como privilégio dos bem nascidos, onde estes faziam parte do cotidiano dos deuses, reis e heróis, tanto que em sua mitologia, estes retrataram casais homossexuais como Zeus e Gamimede, Aquiles e Patroclo. Isto ocorria pois, a heterossexualidade era um ato reservado à procriação, sendo assim considerada como uma mera opção, pois se fazia como necessidade natural à relação homossexual, digna de ambientes cultos, e considerada como a legítima manifestação de libido
}

Importante salientar que além dos romanos e gregos, há na história casos de homossexualidade entre os povos egípcios, assírios. Em procedência de tal assertiva Claudiléia Lemes Dias, acadêmica de Direito da PUC/PR, narra: 
Ante a análise das características históricas de cada nação, tem-se que mesmo naquelas consideradas precursoras do ideal da democracia como sinônimo da igualdade de todos frente ao Estado, o reconhecimento de que a união afetiva entre pessoas do mesmo sexo produz efeitos jurídicos análogos aos do casamento tradicional (DIAS, 2005).

Observa-se que a união homossexual, apesar de aceita no período clássico da humanidade, existe grande demonstração de preconceito no que diz respeito da união homoafetiva, muito embora, como anteriormente mencionado, a relação heterossexual era para mera procriação, advém que o conceito de família era procedente nos casos onde havia fertilidade entre ambas as partes, diferente disto, não haveria de ser denominada família a união heterossexual.

Volvendo-se sobre a história do período clássico da homossexualidade, entende-se o porquê de muitos homossexuais não "saírem do armário", ou seja, manter-se contidos em uma atitude aparentemente correta, o que pode ser confirmado com a descrição da digníssima desembargadora Maria Berenice, do que possivelmente ocorre com os homossexuais diante uma sociedade com o julgo consideravelmente repressor:

Psss... Por favor, não fale, cale.

Deixe o silêncio encobrir tudo, penetrar até a alma.

Afinal, é mais fácil acreditar que aquilo que não se ouve, que não se vê, não existe (DIAS, 2004).

Tal omissão passou a ser mais evidente com o advento do cristianismo, onde a formação moral ficou em seu ápice, tanto que muitos verdadeiramente conservadores passaram a pregar, como também acreditar, que os homossexuais e afins irão acabar no 'inferno'. Reforçando tal arrebatadora assertiva alguns tradicionalistas baseiam-se em um dos versículos da bíblia contidos no livro de Levíticos, que dispõe: "Se um homem se deitar com um homem, como se deita com uma mulher, ele deve ser morto, o seu sangue deve ser derramado":

Com o influxo destas passagens bíblicas é que muitos dos preconceituosos da homossexualidade argumentam que Deus abomina os homossexuais. Apesar de que nem sempre o Cristianismo fora contra a homossexualidade, claro exemplo de que homossexualidade nem sempre foi um problema, no século IX, os códigos penais extensos 
por toda a Europa tratavam os atos sexuais de forma bem minuciosa, mas nenhum de seus artigos punia atos homossexuais.

Apesar de tantos preconceitos, a história caminha a passos largos no desenvolvimento da causa 'homo'. As punições em nome da religião e as discriminações em nome da ciência e da moralidade mostram cada vez mais a sua falta de embasamento. Hoje as sociedades vêm compreendendo que a homossexualidade não é boa nem má, sendo apenas uma condição natural que esteve sempre presente em toda a história da humanidade.

Contudo, em outros países, os homossexuais já foram considerados delinqüentes, fato este que ocorreu na Inglaterra no século XIX, onde inúmeros foram enforcados, como também na Rússia nesta mesma época, após descobrirem relacionamentos denominados 'muzhelozhstvo' (VEJA, 2003, p. 64), estes eram mandados para Sibéria para passar aproximadamente até 05 (cinco) anos. Conforme o estudioso Theo André:

Na Alemanha, na época nazista, tal fato não ocorreu diferente, estes tratavam os casos de homossexualidade da mesma maneira que tratavam os judeus, e uma das formas de diferenciá-los fora no campo de concentração vários homens, os quais foram presos acusados de serem homossexuais, usavam uniformes onde os nazistas os estigmatizavam com um triângulo rosa. Em 1895, um dos mais famosos escritores irlandeses, Oscar Wilde fora acusado de sodomia ${ }^{3}$, como também de comportamento indecente. Em virtude de tais acusações, o juiz definiu tais atos como 'amor que não ousa dizer nome', mesmo apesar de tal subjetiva definição, o juiz por sua vez o condenou a dois anos de prisão e trabal hos forçados ${ }^{4}$.

Anos depois, os homossexuais de 'criminosos' passaram a ser reconhecidos por doentes, mais especificamente como 'portadores de anomalias', e poderiam ser conduzidos da depressão até ao suicídio, como também teriam propensão a cometer crimes. Logo após a discriminação taxativa sobre os relacionamentos homossexuais, genericamente, muitos países passam a fazer estudos sobre o comportamento homossexual, e no Brasil não é diferente, tanto que conforme uma equipe do Laboratório de Antropologia do Instituto de

${ }^{3}$ s.f. cópula anal.

${ }^{4}$ André, Theo. Os Homossexuais e a Aceitação social. Uma Trajetória Contra o Preconceito. Disponível em: বttp:// novahomoacores.no.sapo.pt/notasdahistoria.htm\#A . Acesso em: 14 ago. 2005.

Revista de Direito Púbuco, LondRinA, V. 3, N. 2, P. 235-253, m Al/AGO. 2008. 
Identificação do Rio de Janeiro, inicia um estudo sobre a constituição morfológica de 184 (cento e oitenta e quatro) homossexuais visando identificar caracteres biotipológicos 5 .

Sobre 0 aspecto religioso deste período, algo que se tornou mundialmente conhecido, foi à publicação de um livro escrito por um teólogo anglicano Derrick S. Bailey, intitulado na versão brasileira de, 'Homossexualismo ${ }^{6}$ e tradição cristã ocidental'. Este livro fora um dos primeiros desafios sérios contra a condenação bíblica no que diz respeito sobre a homossexualidade, no referido livro, menciona a tese de que Sodoma e Gomorra foram destruídas não por causa das práticas homossexuais, mas por falta de hospitalidade, o que acarretou um grande alívio no coração dos homossexuais.

Um fato marcante e publicado em diversos jornais e revistas, não poderia deixar de ser narrado, pois foi através dele que se deu o início da parada do 'orgulho gay', que originou-se em 28 de junho de 1969, isto porque, nove detetives à paisana entraram no bar Stonewall, no bairro Greenwich Village, em Nova York, expulsaram cerca de 200 fregueses que lá estavam e prenderam o gerente, um porteiro e três travestis. Ao se retirarem do bar com os detentos, encontraram uma multidão irritada, que começaram a atirar-Ihes pedras e garrafas. 0 contra tempo ocorrido no bar Stonewall deu origem ao Gay Power (poder gay), que marcou 0 início do protesto público contra a discriminação de homossexuais, em virtude disto, o dia 28 do mês junho passou a ser mundialmente "o dia do orgulho gay".

Nesta mesma época, em alguns estados brasileiros, diversos grupos homossexuais surgiram, dentre eles, o Triângulo Rosa e Grupo Arco Íris ${ }^{7}$ no Rio de Janeiro, Grupo Gay da Somos em São Paulo, Dialogay do Sergipe, Grupo Dignidade de Curitiba, Grupo Gay do Amazonas, Nuances de Porto Alegre, Grupo Lésbico e Gay da Bahia, sendo provavelmente este último grupo o primeiro a ser registrado como sociedade civil em 1983, e daí em diante, no Brasil, vários encontros e movimentos passaram a ocorrer.

${ }^{5}$ André, Theo. Os Homossexuais e a Aceitação social. Uma Trajetória Contra o Preconceito. Disponível em: বttp:// novahomoacores.no.sapo.pt/notasdahistoria.htm\#A >. Acesso em: 14 ago. 2005.

${ }^{6}$ Faz-se necessário relatar que atualmente não há uso do sufixo 'ismo', para denominar as relações homossexuais, pois tal sufixo tem conotação de doença, o que atualmente sabe-se que não é verídico. Entretanto, o motivo o qual fora escrito Homossexualismo nesta lauda ao citar um dos primeiros livros que sutilmente proferiu um favorecimento positivo das relações de mesmo sexo, fora para manter a autenticidade do título do livro do escritor anglicano.

${ }^{7}$ M inidicionário Aurélio. Arco-íris: sm2n. Fenômeno resultante da dispersão de luz solar em gotículas de água suspensas no ar, e que se mostra como um conjunto de arcos coloridos. 
Dentre tantos acontecimentos, não poderia ser passado em branco a Lei $\mathrm{n} . \underline{0}$ $1.151 / 95^{8}$, onde a ex-deputada Marta Suplicy propondo a legalização da união civil entre pessoas do mesmo sexo, no caso de aprovação, tal projeto se transformaria em uma das primeiras leis no país a reconhecer os direitos dos homossexuais, que infelizmente não obteve êxitos. Quatro anos após esta votação, o deputado federal Nilmário M iranda do PTM G sugeriu a alteração da Lei 7.716/99, a qual foi aprovada no senado, definindo também como crime a discriminação contra homossexuais, da mesma forma que se penalizam os atos de preconceito contra a raça, cor, etnia, religião e procedência nacional.

Outro fato a favor do direito dos homossexuais foi às decisões judiciais ocorridas, entre elas, o reconhecimento da união de pessoas do mesmo sexo. Exemplo disso, é a decisão do desembargador M ello Serra, do Rio de Janeiro, em que Henrique Berbert Silveira pôde herdar o patrimônio de seu parceiro homossexual, Ary Pinto Mesquita (apud BRITO, 2000).

Apesar dos avanços a respeito do tema, não se pode afirmar que a sociedade como um todo, isto é, tanto brasileiros quanto estrangeiros, comunguem da mesma opinião. Há muito ainda a se fazer para que no futuro, não tão distante, os homossexuais possam assumir a sua "condição" e o preconceito seja apenas história.

\section{Aspectos da homossexualidade}

Há uma análise sobre alguns dos aspectos que tangem a homossexualidade, que são eles: a religião, a medicina e a psicologia. Com base nas pesquisas realizadas, constatouse que grande parte da discriminação contra os homossexuais ocorre por meio da influência religiosa que todos os seres humanos têm, com base nestes preceitos, observa-se que a igreja tem grande preocupação sobre o que diz respeito à família, que é, por sua vez, naturalmente formada pela união de um homem e uma mulher, e que tal junção não seja pelo simples propósito de vir a satisfazer um desejo, mas sim, para procriar. Em outras palavras, conforme o relato de Elaíne Cristina de Oliveira e M elo:

\footnotetext{
${ }^{8}$ Projeto de Lei n. 1.151, de 1995, que disciplina a união civil entre pessoas do mesmo sexo e dá outras providências.
} 
A igreja repudia a busca do homem somente pelo prazer em suas relações sexuais, como se concebe quando se unem duas pessoas do mesmo sexo, uma vez que a natureza biológica não permite a procriação a partir dessas relações.

Apesar desta "teoria da procriação", é importante ressaltar que muitos heterossexuais não têm a intenção de procriar, e o mesmo ocorre com alguns dos cidadãos homossexuais.

Mesmo com tanto repúdio por parte dos religiosos, em junho de 2004, 0 presbiteriano Roberto Gonzáles, abençoou catorze homossexuais, durante a Conferência M undial da International Gays and Lesbians Association, no Rio de Janeiro, o que demonstra que paulatinamente os homossexuais vêm alcançando seu espaço.

Após inúmeras buscas por uma resposta sob o aspecto religioso, em virtude da homossexualidade, tal assunto foi levado ao domínio da medicina, e mesmo havendo por parte dos cientistas grande descrença em face da existência divina, estes sofreram grande influência religiosa no que diz respeito aos homossexuais, estes passaram a diagnosticar os homossexuais, como pessoas com diminuição das faculdades mentais, de mal contagioso, decorrente de algum defeito genético, e passaram a estudar o sistema nervoso central, como também os hormônios e o funcionamento do aparelho genital dos homossexuais. Apesar de tantos estudos acerca da homossexualidade, estes não obtiveram quaisquer explicações, deixando, assim, de considerar os homossexuais como doentes, remetendo-os desde então, para um outro âmbito da medicina, a psicologia. Como observa Oscar Wilde:

0 médico austro-húngaro Karoly Maria Benkert, cria o termo homossexual, que passa a ser usado amplamente, passando o homossexualismo a ser tratado como categoria científica, uma "anomalia" a ser estudada também pela psicologia. ${ }^{9}$

Importante pontuar que, antigamente a medicina 'olhava' a homossexualidade como uma doença, e por isso, os relacionamentos de pessoas de mesmo sexo, era denominado de 'homossexualismo', pois como foi explicado, o sufixo 'ismo' é indicativo de doença. Atualmente, segundo os médicos, os homossexuais não podem ser considerados mais como pessoas com um diagnóstico médico, pois para estes, os transtornos homossexuais decorrem muito mais de sua discriminação e repressão social derivados do

${ }^{9}$ Disponível no site: www.jusnavegandi.com.br, em Posições Contrárias e Favoráveis a Homoafetividade. Acesso em junho/ 2005. 
preconceito do seu desvio sexual, do que por algum sintoma doentio. Com isto, o fator homossexual, tanto entre homens como mulheres, passou a ser denominado como homossexualidade.

Dentre os profissionais da área psicológica, a opinião é díspar, enquanto alguns afirmam que esta 'opção' sexual advém de algum fato marcante na infância, por ausência de um pai ou mãe, por exemplo, outros narram a assertiva de que da mesma forma que muitos indivíduos nascem e se consideram heterossexuais, o mesmo ocorre com os homossexuais.

Para muitos estudiosos do ramo da psicologia, a homossexualidade não é uma perversão e muito menos uma doença, mas sim, segundo ensina Correia apud Freud, que a 'homossexualidade é uma variação do desenvolvimento sexual', onde segundo este estudioso, os fatores potencializadores seriam:

Um intenso enlace infantil de caráter erótico e esquecido depois pelo indivíduo, a um sujeito feminino, geralmente a mãe, enlace provocado ou favorecido pela excessiva ternura apoiado depois por um distanciamento do pai da vida infantil do filho (CORREIA, 1997).

Diante desta narrativa, nota-se que é certo que a "opção" de ser homossexual é inexistente, como também o fato de ser heterossexual não é uma escolha, apesar de ser bem confortável, pois esta é a 'opção' da maioria da sociedade. Certamente, o pensamento de Freud, conforme citou Correia, não estava tão longe do que a óptica da atualidade.

Isto porque, contemporaneamente, a homossexualidade vem passando por uma fase de menor preconceito e, conseqüentemente, ganhando um nível maior de aceitação no que tange à sociedade, mas mesmo assim, com certeza há muitos homossexuais vivendo de uma forma cheia de minudências, onde somente o parceiro e mais ninguém sabe de sua vida afetiva. Neste sentido, Klecius pontua que:

As maiorias dos homossexuais acostumaram em ficarem calados e ouvir pessoas tecendo comentários sobre as formas generosas de uma secretária, de uma mulher que conheceram em determinado lugar, e assim sucessivamente, quando não resolvem brincar com a sexualidade alheia. Mediante tais constrangimentos, e até incompreensão, pois muitos dos que resolvem confessar sua opção sexual a um amigo ou parente, estes acabam indicando um médico, ou psicólogo, ou até se caso forem aos pais tal confissão, este os mandam para fora de casa, e em alguns casos chegam a até cortar toda a relação familiar (VEJA, 2003). 
0 que demonstra que ao contrário do que se pensa, nenhum dos homossexuais, optaram por tal caminho, como discorre Carmita Abdo, psiquiatra e sexóloga em uma entrevista fornecida para a Revista Veja, onde relata que, 'se a sexualidade dependesse de uma escolha puramente racional, as pessoas não seriam homossexuais' (VEJA, 2003).

Importante salientar que dentre os muitos estudos acerca da homossexualidade, foi analisada a possibilidade de haver mudanças na orientação sexual de um homossexual. Após vários estudos, foi descoberto que "há possibilidades, por meio de técnicas aversivas, de se reprimir o comportamento homossexual, no sentido de apenas reduzir o desejo homossexual e aumentar o heterossexual, porém não há nenhum método científico ou não de tornar um homossexual cem por cento heterossexual" (BORGES, 2005).

Por isso, há tantas manifestações sobre a união homoafetiva, porque, para os homossexuais, além de ser um casamento que trará responsabilidades, também significará a união pública de duas pessoas que se amam, também está o anseio emocional de ser aceito e respeitado por seus semelhantes.

\section{A união homossexual no âmbito jurídico do direito brasileiro}

Sabe-se que no Brasil, há certa e demasiada tentativa de se normatizar os vínculos afetivos homossexuais, embora este venha a gerar um sistema de exclusão permeado de preconceitos pelo fato de que esta união homoafetiva seria a mesma de uma união heterossexual, e isto viria a ser uma agressão ao instituto familiar que por sua vez, através da Declaração Universal dos Direitos Humanos das Nações Unidas como o Estado, vem a ser consagrada e protegida, por ser elemento fundamental e natural do meio social.

Não resta dúvidas que a lei deve proteger a relação homossexual, mas jamais deve ficar esquecido que o Brasil, por ser um país democrático, visa ser um Estado composto de uma sociedade livre, justa, e que é a favor do bem-estar de todos os seres humanos, sem preconceitos de origem, raça, sexo, cor, idade e quaisquer outras formas de discriminação, como obsta na Constituição Federal em seus artigos 1 e 3, incisos I e IV, mas em antítese a esta afirmação, encontra-se no artigo 226 e seu §3ำ da mesma constituição, a seguinte norma: 
art. 226 - A família, base da sociedade tem especial proteção do Estado.

§30 - Para efeito da proteção do Estado, é reconhecida a União Estável entre o homem e mulher como entidade familiar, devendo a lei facilitar sua conversão em casamento (C.F.,2001).

Entretanto,

dentre as inúmeras teorias sobre a natureza do matrimônio na história do direito, nenhuma abrangeu a hipótese de sua realização entre pessoas de um mesmo sexo, embora a homossexualidade tenha existido em todas as épocas. Tudo sempre se discutiu, mas uma coisa era certa, o casamento entre pessoas do mesmo sexo não era nulo, nem anulável, mas inexistente (POLETTI, 2004).

No que confere a lei 1.151 de 1995, que por sua vez é intitulada pela ex-deputada Marta Suplicy como 'Um legítimo direito de cidadania', esta vem disciplinar a união civil de pessoas do mesmo sexo, pelo motivo que infere Correia apud Suplicy:

A relação dos vários países que possuem legislação a respeito da união civil e sobre a proibição de discriminação por motivo de orientação sexual, a relação dos deputados que integram a comissão responsável pela análise e parecer sobre 0 projeto e duas reportagens publicadas pela revista Manchete e pelo jornal 0 Estado de São Paulo a respeito do projeto de lei que é composto por 18 artigos. Basicamente 0 projeto propõe 0 direito à herança, sucessão, benefícios previdenciários, seguro saúde conjunto, declaração conjunta do imposto de renda e 0 direito à nacionalidade no caso de estrangeiros. Ao contrário do muitas pessoas pensam, em momento algum o projeto se refere a palavra casamento, mas sim a união civil. Este talvez seja um dos principais motivos e rejeição do projeto por parte da sociedade, uma vez que a palavra casamento é associada à imagem de uma família composta de marido, mulher e filhos, amparada pelo Estado e abençoada pela Igreja. Além do mais, o casamento, como ato jurídico que é, se realizado entre pessoas do mesmo sexo, nos colocaria diante de um ato jurídico nulo (CORREIA, 1997).

Ao observar tais relatos sobre este projeto de lei, nota-se que embora visar uma regulamentação da união homossexual, através de uma união estável, a qual ocorre também entre heterossexuais, possui outros objetivos, como vislumbra Correia (1997):

Os fins do casamento são distintos da união civil, uma vez que o casamento tem por finalidade a procriação, ajuda mútua e criação dos filhos. Já a união civil, tem por finalidade estabelecer um contrato de união entre pessoas do mesmo sexo, que por um motivo qualquer tenham uma orientação sexual diferente das outras, 0 que as torna incapazes de constituir uma família tradicional pelo fato de não sentirem atração sexual pelo sexo oposto, mas que ao mesmo tempo, estabeleça um contrato que assegure aos contratantes 0 direito de herança e sucessão, aos

Revista de Direito Púbuco, LondRINA, V. 3, N. 2, P. 235-253, m Al/AGO. 2008. 
benefícios previdenciários, ao seguro saúde conjunto, declaração conjunta de imposto de renda e o direito à nacionalidade no caso de estrangeiros.

Ressalvando que no que consta na lei 1151/95, a união civil será celebrada em cartório, mas que as pessoas envolvidas, sejam solteiras, viúvas ou divorciadas, como também não poderão se casar durante a vigência do mesmo, devendo ser disposto nas cláusulas contratuais da união civil o patrimônio, os deveres, impedimentos e obrigações mútuas, sendo causa de exclusão, a desistência de uma das partes ou morte de um dos contratantes.

Com a omissão legislativa sobre as uniões homossexuais, estas eram dadas como direito das obrigações, então denominadas como sociedade de fato, tendo ainda como obrigação, um dos 'sócios' provar sua efetiva participação na aquisição de bens amealhados durante o período do convívio social.

Com exceção a alguns juízes e tribunais do Rio Grande do Sul, em seus mais diversos campos de atuação, encontram-se num período de adaptação recente de julgamentos, principalmente no que pertine às interpretações de direito sucessório, previdenciário, dentre outros. Mas concomitantemente, analisando alguns julgados, nota-se o quão vem evoluindo o entendimento dos juízes e tribunais, como pode ser compulsado in verbis

EM ENTA: UNIÃO HOM OSSEXUAL. RECONHECIMENTO. PARTILHA DO PATRIM ÔNIO. CONTRIBUIÇÃO DOS PARCEIROS. MEAÇÃO. Não se permite mais o faraismo de desconhecer a existência de uniões entre pessoas do mesmo sexo e a produção de efeitos jurídicos derivados destas relações homoafetivas. Embora permeadas de preconceitos, são realidades que o Judiciário não pode ignorar, mesmo em sua natural atividade retardatária. Nelas remanescem conseqüências semelhantes às que vigoram nas relações de afeto, buscando-se sempre a aplicação da analogia e dos princípios gerais do direito, relevados sempre os princípios constitucionais da dignidade humana e da igualdade. Desta forma, o patrimônio havido na constância do relacionamento deve ser partilhado como na união estável, paradigma supletivo onde se debruça a melhor hermenêutica. Apelação provida, em parte, para assegurar a divisão do acervo entre os parceiros. Voto vencido (WARKEN, 2003).

0 julgado anteposto enfrenta e afasta o preconceito existente contra uma sociedade convivencial de fato, proporcionando a meação ao sócio supérstite (DIAS, 2001), como elogiam Carlos Eduardo e Roberto Luiz Warken's. E em menção ao referido julgado, há de se acrescentar um relato de Dias (2001): 
A omissão do legislador em regulamentar as uniões de pessoas do mesmo sexo muitas vezes foi vista como deliberada intenção de excluir a possibilidade de se extraírem dessas relações efeitos jurídicos. Ou seja, a ausência de previsão legal não possibilitaria o reconhecimento de quaisquer direitos. Não se encontrando no ordenamento jurídico dispositivos legais que, de forma expressa, reconhecessem direitos ou obrigações, a tendência era o indeferimento da petição inicial. Essa postura é retratada na ação que deu ensejo ao presente julgamento. A união afetiva homossexual pela convivência do autor com o de cujus ${ }^{10}$ por quase 15 anos deu ensejo à ação que foi nominada de 'declaratória de reconhecimento de sociedade de fato'. De forma alternativa, buscou 0 autor direitos sucessórios ou indenização por serviços prestados. Sem instituir o processo, o magistrado julgou como improcedente a ação, invocando como fundamento o inciso I do art. 269 do CPC, que prevê a extinção do processo com julgamento do mérito pelo desacolhimento do pedido do autor. 0 recurso foi distribuído ao Desembargador José Ataídes Siqueira Trindade. A 8a câmara cível, por unanimidade de votos, deu provimento ao recurso, reformando a sentença. Reconhecendo que a inicial descrevia a existência de um vínculo familiar, foi afirmada, a possibilidade jurídica do pedido e determinado o prosseguimento da ação, para que as partes tragam as provas de suas alegações.

Nesta óptica, há de se concordar que mesmo sem nenhuma legislação pertinente a união homossexual, sabiamente, juizes e tribunais vêm tutelando jurisdicionalmente os homossexuais, que com muito esforço ultrapassa a lei fria, muito embora, esta nunca proibiu a relação afetiva de pessoas de mesmo sexo, pois até hoje, não foram gerados mecanismos legais que venham a amparar a união homoafetiva, deixando uma enorme lacuna sobre 0 assunto em tela.

Importante observar que tais valores, como explicitado anteriormente, passaram a existir no âmbito social após o advento do cristianismo, pois até então, nenhuma demonstração preconceituosa aparente ocorria acerca da homossexualidade. Independente de ser antes ou não da emersão da religião no meio social, o movimento ocorre em defesa do casamento de pessoas do mesmo sexo, no seio jurídico e não uma autorização para o casamento religioso, e nesta área, cada doutrina é livre para estabelecer as regras que bem entender (CHIARINI JÚNIOR, 2005).

No que pertine às uniões homossexuais, cujo debate é o que norteia esta pesquisa, verifica-se uma absoluta ausência de regulamentação, seja em sede de legislação constitucional como infraconstitucional, nem mesmo a notável lei $10.406 / 2002$, que se

${ }^{10}$ Esta expressão é usada comumente como sinônimo de 'pessoa falecida', numa figura eufemística substitutiva de 'defunto' ou 'morto'. Estas duas palavras foram, na verdade, retiradas de uma expressão mais longa, que é: "De cujus successione agitur" e significa 'de cuja sucessão se trata'. Situa-se, portanto, no contexto do direito sucessório, do caso daquela pessoa falecida, que deixou bens materiais, e cuja sucessão (direito de herança) é regulada pelas normas jurídicas. Disponível no site: http://www.geocities.com/Athens/Agora/1417/latimjur.htm.

Revista de Direito Público, Londrina, v. 3, N. 2, P. 235-253, m Ai/Ago. 2008. 
preferiu denominar Novo Código Civil, foi capaz ou simplesmente não quis acompanhar a necessidade veemente de regulamentação que tais uniões ensejam.

É certo que o direito não regula os sentimentos, contudo, conforme dispõe Aguiar:

0 direito sobre os efeitos que a conduta determinada por esse afeto pode representar como fonte de direitos e deveres, criadores de relações jurídicas previstas nos diversos ramos do ordenamento, algumas ingressando no Direito de Família, como o matrimônio, e, hoje, a união estável, outras ficando à margem dele, contempladas no Direito das Obrigações, das Coisas, das Sucessões, mesmo no Direito Penal, quando a crise da relação chega ao paroxismo do crime, e assim por diante.

Por outro lado, torna-se impossível esta situação, pois como é sabido, os fatos sociais são a fonte criadora do direito, e que pode, mas normalmente deve-se exteriorizar através da norma.

Ao contrário do que ocorria às uniões, a família de hoje é constituída por afeto, devendo desta forma ser um conjunto de pessoas unidas pelo amor, pelo carinho, pela sinceridade, pela honestidade e pela lealdade e o casamento deveria ser o principal meio de se alcançar e de se constituir essa família (THOM AZ).

Consigna-se que a união entre homossexuais é tão bloqueada pelos seres humanos heterossexuais brasileiros, que dá a impressão de que esta não possui nenhuma forma de ser legalizada no ordenamento jurídico do Brasil. Mas, se houver vida em comum, laços afetivos e divisão de despesas, não há como se negar efeitos jurídicos à união homossexual (PORTANOVA, 2002). Como também cumpre dizer o que dispõe Portanova apud Kelsen: 0 que não é proibido é permitido.

Diante dessa perspectiva, constata-se, sem maior dificuldade, que estão vedadas as distinções entre os casais heterossexuais e aqueles formados por pessoas do mesmo sexo, visto que, pelo princípio da igualdade, seja em sua acepção formal ou material, entende-se que houve uma equiparação entre os indivíduos, ou seja, a orientação sexual não pode ser considerada como fator discriminatório, por que senão, não haveria motivo de existir lacuna na justiça no que diz respeito à união de afeto homossexual.

Luta-se apenas pela autorização do casamento civil na união homossexual, aquele reconhecido pelo estado, mas por ser o Brasil um país laico, este não consegue abster-se da tradição preconceituosa que de certa forma faz-se essência do seres humanos, pois estes 
preconceituam tudo o que lhes é diferente de si. Mas como dizia uma letra mui conhecida pela juventude do século XX, que descreve bem a homossexualidade e o preconceito, é que os homossexuais, são seres humanos fantásticos, com poderes titânicos, foi um moreno simpático por quem me apaixonei, e hoje estou tão eufórico, com mil pedaços biônicos, ontem eu era católico, ai, hoje eu sou um gay! Abra sua mente, gay também é gente, baiano fala oxente, e come vatapá, você pode ser gótico ser punk ou skinhead, tem gay que é M uhamed, tentando camuflar (Allah meu bom Allah) Faça bem a barba, arranque seu bigode gaúcho também pode, não tem que disfarçar. Ai como dói! ${ }^{11}$

Em suma, uma sociedade que se quer aberta, justa, livre pluralista, solidária, fraterna e democrática e contemporânea não pode conviver com tal cruel discriminação quando a palavra de ordem é a cidadania.

\section{Conclusão}

Embora as uniões homoafetivas encontrem inúmeros óbices que inviabilizam sua efetiva juridicização, é notável o avanço jurisprudencial no sentido de reconhecer direitos antes negados, ainda que a tendência nos tribunais limite-se apenas à concessão de direitos de cunho patrimonial, sem, no entanto, admitir como hipótese destes serem realmente uma família, assim como as demais uniões heterossexuais.

Como foi analisado desde o princípio na tese abordada, bem como em função dos mais variados fatos noticiados pela imprensa, demonstrando as tendências mundiais e nacionais sobre a união de homossexuais, mostra o quão é necessário o legislador brasileiro passe a adotar alguma posição coerente diante dos casos concretos, e que não fique só no papel, como é o caso do projeto da Deputada Marta Suplicy. Porém há de convir que julgar situações que envolvem a moral sexual não é uma função muito fácil, tanto que a homossexualidade está envolta de uma profunda aura de silêncio. Diante dos aspectos abordados, observa-se que há uma enorme dificuldade dos legisladores decidirem por quaisquer decisões no que tange a homossexualidade, isto porque desde 0 início, a sociedade vem sendo imersa sobre pseudomoralismos, conseqüência de anos de crendices infundadas.

${ }^{11}$ Robocop Gay. Mamonas Assinas. Letra disponível no site: www.mamonasassassinas.letras.terra.com.br/letras/24149/. 
Embora haja tanta resistência às uniões homossexuais, muitos legisladores estão sendo sensibilizados, fazendo com que muitas decisões positivas pairem sobre 0 ordenamento jurídico brasileiro. No entanto, mesmo em meio a tantas manifestações, muitas lacunas existem no direito brasileiro, como por exemplo a legalização da união dentre duas pessoas de mesmo sexo, pois fantasiar com um mundo idealizado para fugir da realidade dura e concreta não diminui os problemas existentes na vida real, mas sim, faz aumentar as dificuldades que se mostram muitas vezes intransponíveis devido ao grande preconceito que assola em meio de uma sociedade que se encontra desequilibrada, primando por uma suposta 'modernidade' ao mesmo tempo em que se agarra a alguns tradicionalismos desnecessários muitos estudiosos, legisladores, advogados vêm ultrapassando estas barreiras aparentemente impossíveis de se vencer. Vale ressaltar que 0 presente tema inferiu-se sobre o porquê do direito brasileiro ainda não legalizar a união homoafetiva, sendo que de certa forma já o vem fazendo, mesmo que esporadicamente.

Os homossexuais, por trás da idéia da legalização de sua homoafetividade buscam 0 compromisso de assumir publicamente os mesmos deveres e responsabilidades, como também a usufruir os mesmos direitos concedidos aos casais heterossexuais, pois está no anseio emocional de qualquer ser humano, o desejo de ser aceito, respeitado e dignificado por seus semelhantes.

0 indeferimento dos projetos até hoje apresentados acerca da legalização da união homoafetiva que até o presente momento vem sendo dado por muitos dos participantes do ordenamento jurídico brasileiro está sendo baseado, em um bolo de preconceitos religiosos que há muitos anos vêm sendo inseridos no cotidiano de todos os cidadãos, e assim, fazendo ser esquecido que um indivíduo, além de ser homossexual ou heterossexual, é um ser humano, munido de direitos, deveres e sentimentos, e por isso deve ser respeitado, não importando sua 'opção' sexual, sua raça, ou sua condição econômica e social. 0 que se indaga até então, não é a condição de ser 'homo' ou 'hetero', mas sim, o fato dos cidadãos e cidadãs, serem iguais perante a lei, sem distinção de qualquer natureza, de acordo com 0 que é retratado na Constituição Federal do Brasil, porém não colocada em prática.

Por fim, diante da questão colocada em autos, o presente artigo não veio impetrar como uma lei, o caminho que deve ser seguido, porém veio lembrar e sugerir aos 
responsáveis pelo direito brasileiro que todos os seres humanos devem ser tratados igualmente, mesmo sendo considerados desiguais perante toda uma sociedade.

\section{Referênciais}

AGUIAR, Ruy Rosado de. ST] , 4a T. Recurso Especial de n. 148.897-M G; Boletim AASP, n. 2057. Associação dos Advogados de São Paulo. Disponível em: www.aasp.org.br/aasp/home/noticias. Acesso em: 14 out. 05.

ALM EIDA, João Ferreira de. A Bíblia Sagrada. Revista e Atualizada no Brasil. 2. ed. São Paulo: Sociedade Bíblica do Brasil, 1993.

ALM EIDA, João Ferreira de. 0 novo testamento, Salmos Provérbios. Edição Revista e Corrigida. Sociedade Bíblica do Brasil, 2003.

ALVES. Alecsander (vulgo 'Dinho'). RASEC Julio. Robocop Gay. Disponível em: বhttp://www.mamonas-assassinas.letras.terra.com.br/letras/24149>. Acesso em: jun. 2005.

ANDRÉ, Theo. Os Homossexuais e a Aceitação social. Uma Trajetória Contra o Preconceito. Disponível em: «ttp://novahomoacores.no.sapo.pt/notasdahistoria.htm>. Acesso em: 14 ago. 2005.

A正VEDO, Álvaro Villaça. Homossexualidade. Revista Jurídica Consulex, v. 8, n. 181, p. 42-43.

ANGHER, Anne Joyce. Brasil, Direito Civil: Legislação. Título II. Série III. 10. ed. São Paulo: Editora Rideel, 2004.

BORGES, Klecius. Homossexualidade. Disponível em: $\varangle w w w . g m a g a z i n e . c o m . b r>$. Acesso em 20 set. 2005.

BRITO, Fernanda de Almeida. União Afetiva entre Homossexuais e seus Aspectos Jurídicos. São Paulo: LTR, 2000. 47 p.

CHIARINI JÚNIOR, Enéas Castilho. A Igreja Católica e os Homossexuais: a gota d'água. Disponível em: $\varangle w w w . j u s n a v e g a n d i . c o m . b r>$ Acesso em: jun. 2005.

CORREIA, Jadson Dias. União civil entre pessoas do mesmo sexo (Projeto de Lei 1151/95). Jus Navigandi, Teresina, v. 1, n. 10, abr. 1997. Disponível em:

४ttp://jus2.uol.com.br/doutrina/texto.asp? >. Acesso em: 13 ago. 2005.

DIAS, M aria Berenice. União Homossexual: o preconceito e a justiça. Porto Alegre: Livraria do Advogado, 2001.

. Conversando sobre Homoafetividade. Porto Alegre: Livraria do Advogado, 2004. 
. Homoafetividade: 0 que diz a justiça!: as pioneiras decisões do Tribunal de Justiça do Rio Grande do Sul que reconhecem direitos às uniões homossexuais. Porto Alegre: Livraria do Advogado, 2003. . Um voto para a Homoafetividade. Revista Jurídica Consulex, v. 8. 15 abr. 2004. . Família, ética e afeto - Destaque. Revista Jurídica Consulex. V. 8, n. 174, 2004. jan. 2005.

. É dever da jurisprudência inovar pelo novo. Revista Jurídica Consulex, v. 9, n. 193, 31

DINIZ, M aria Helena. Curso de Direito Civil. Direitos de Família. 5. ed. São Paulo: Saraiva, 2002.

M ELO, Elaíne Cristina de Oliveira e. Um novo modelo de família. Aspectos sócio-jurídicos da união entre homossexuais. Disponível em:

বtttp://jus2.uol.com.br/doutrina/texto. asp?id=6496>.

M IRANDA, Francisco Cavalcante Pontes. Tratado de Direito de Família: Direito M atrimonial. 3. ed. São Paulo: M ax Limonad, 1947. p. 296-297. v. 1.

M IRANDA, Sandra Julien. Brasil: Constituição Federal de 1998. São Paulo: Editora Rideel, 2001.

NÓBREGA, Airton Rocha. Apontamentos sobre a Instituição do casamento. Advogando na área de família. Prática Jurídica. v. 3, n. 24, 31 mar. 2004.

O LATIM Jurídico. Disponível em:

বhttp://www.geocities.com/Athens/Agora/1417/latimjur.htm>. Acesso em: jul. 2005.

PINHEIRO, Fabíola Christina de Souza. Uniões homoafetivas. Do preconceito ao reconhecimento como núcleo de família. Jus Navigandi, Teresina, v. 9, n. 625, 25 mar. 2005. Disponível em: «ttp://jus2.uol.com.br/doutrina/texto.asp?id=6495>.

POLETTI, Ronaldo Rebello de Britto. Casamento entre Homossexuais. Revista Jurídica Consulex, v. 8, n. 180, 15 jul. 2004.

PORTANOVA, Rui. Quanto ao M érito - Lacuna. Revista brasileira de Direito de Família, Porto Alegre, n. 15, abr./jun. 2002.

REVISTA, Veja. Gays: a vida fora do armário. Editora Abril. Ed. 1808, v. 36, n. 25, p. 75.25 jun. 2003.

RESPOSTAS ao Impossível. Disponível em:

বhttp://wfera.tripod.com/respostasaoimpossivel/id70.html>.

WARKEN, Carlos Eduardo. Roberto Luiz Warken. A instituição da so ciedade convivencial entre pessoas de mesmo sexo. A discriminação legalizada e a oportunidade em afastá-la. Jus 
Navigandi, Teresina, v. 7, n. 61, jan. 2003. Disponível em: বhttp://jus2.uol.com.br/doutrina/texto.asp?id=3578>. Acesso em: ago. 2005.

WILDE, Oscar. Os retoques históricos na homossexualidade. Disponível em: বhttp:www.geocites.com/projetoliberdade/sodoma.html>. Acesso em: ago. 2005. 